\title{
The Encyclopedic Stance of Kant's Transcendental Philosophy
}

Nikolay Milkov (Paderborn)

1. Kant and the idea of philosophical encyclopedia

Immanuel Kant is widely acknowledged to have been the most fruitful and influential philosopher since Aristotle. Unfortunately, it is not so clear what makes Kant's philosophy thus fruitful and influential. Typically, this question is answered with reference to what Kant himself called "Copernican Revolution" which he allegedly brought about in philosophy: instead of philosophically exploring the world, Kant investigated the possibility of cognizing the world through human reason $(\mathrm{KrV}, \mathrm{B}$ xvi-Xvii).

The objective of this paper is to present a new perspective of assessing Kant's project to renew philosophy, with the hope that it will help to better answer the aforementioned question. Our claim is that the profound influence of Kant in philosophy is an implication of a radical change in the style of the discipline he introduced. Descartes produced philosophical “meditations," John Locke and David Hume, philosophical “essays,” and Leibniz both essays and meditations. In the pre-Kant Germany, Christian Wolff successfully practiced systematic philosophy. The objective of his systematic studies, decisively inspired by the new achievements of mathematics and mathematical sciences, was to investigate particular philosophical disciplines — ontology, rational psychology, and rational cosmology — with the methods used in a scientific theory: axiomatization, substantiation, and argumentation.

Kant's project was different. He not only followed a systematic way of doing philosophy, but also introduced a kind of logically informed encyclopedic approach to it. ${ }^{1}$ Unfortunately, Kant did not always recognize it this way. Only in the last years of his life did he see his transcendental philosophy as "an architectonic encyclopedia which a priori puts the formal as a foundation [zum Grunde]" (OP, AA 21: 109). Usually, Kant spoke of his transcendental philosophy simply as a systematic study. Understandably, this way of seeing his philosophy was repeated by the interpreters.

The thesis of the present paper is that the conventional interpretation of Kant's project for transcendental philosophy is less helpful in identifying its true nature. Of course, Kant's

\footnotetext{
${ }^{1}$ This interpretation is supported by the biographical fact that while David Hume made his discovery that we do not experience causation, when he was 23 in 1734, on which his A Treatise of Human Nature (1738) was based, Kant was 45 when he, in 1759, was waked up from his "dogmatic slumber" by Hume's (not by his own) discovery. Kant needed 12 further years when he, at 57, produced his KrV. His task was much more complex than that of Hume.
} 
transcendental philosophy is systematic, but it is more than that. It deliberately tries to put together the main philosophical discoveries achieved by conceptual analyses, systematic explorations, Socratic dialogues, philosophical meditations, and writing essays in more than two millennia, bringing them into a systematic whole. Moreover, Kant's system is logically organized - parts of it cannot be changed without destroying the whole because every one of its elements is logically connected to the rest (Prol, AA 4: 20).

Without any doubt, the historical context of this new approach in philosophy was connected with the encyclopedic projects of Kant's time, in particular, the Encyclopédie of d'Alambert and Diderot. Kant grew into a philosopher exactly in the years in which the Encyclopédie took shape: its 35 volumes were published between 1751 and 1780. Most importantly, the Encyclopédie was the banner of the French enlightenment and its main product: publishing its volumes meant victory for the enlightenment. And, as we know quite well today, Kant understood himself as, if anything, a man of the enlightenment.

The main idea of the Encyclopédie was the classification of sciences, their presentation as organic elements (branches) of the "tree of knowledge." Another metaphor used by the French encyclopedists, however, was not thus organic. D'Alambert and Diderot also saw their work as mappemonde, an atlas that could be helpful in navigating the world of knowledge. The French encyclopedists followed the Cyclopedia of Ephraim Chambers (1728) who, in turn, adopted the program for instauratio magna of all sciences of Francis Bacon. The similarities between Bacon's project and that of the Encyclopédie were, in fact, so close that the authors of the latter were sometimes accused of plagiarism (Darnton 1984: 218). In particular, it was Bacon who introduced the project for comprehensively depicting the "tree of knowledge." In the face of these facts, the motto of $\mathrm{KrV}$, a passage from Bacon's Instauratio magna, clearly underpins the thesis of the encyclopedic stance of transcendental philosophy.

2. Kant's lectures on philosophical encyclopedia

Kant was perhaps the first philosopher in Germany to academically teach the discipline "philosophical encyclopedia." 2 He taught it 10 times, exactly in the period when he conceived of the project and then wrote KrV: from 1767/8 till 1781/2 (Lehmann 1961a, 69). Kant closely followed J. G. H. Feder's Grundriß der Philosophischen Wissenschaften (1767). This was a

\footnotetext{
${ }^{2}$ An exception was Alexander Baumgarten (1714-1762) who lectured on philosophical encyclopedia in the last years of his life. However, his lectures on this sub-discipline (1769) were only published posthumously, when Kant had already lectured on it. Apparently, Kant did not start his lectures on philosophical encyclopedia under Baumgarten's influence.
} 
generalist, introductory course in philosophy. Kant's objective was to make philosophy students acquainted with the main philosophical disciplines. As he himself put it in his lectures, "the encyclopedia is a short excerpt from the whole science [of philosophy]. It is part of it to help one to make to himself an idea of the whole" (PhilEnz, AA 29: 32). In his last encyclopedic lectures of 1781/2, which were eventually published in 1961, Kant shortly outlined the tasks of logic, metaphysics, "moral maxims" and empirical psychology. It is quite possible that the earlier lectures were more comprehensive. Importantly enough, Kant classified his lectures on philosophical encyclopedia, together with those on pedagogy, natural rights and natural theology, into a second group of four. (In the first group were logic, metaphysics, moral, and physical geography.) Clearly, they were not of prime and direct philosophical importance to him.

Following the instructions of the Prussian Ministry of Education of the time, Kant widely used compendia in his lectures. He was not picky: the compendia he followed were not always of best quality (Lehmann 1961b, 7). Generally, they were authored by Wolfians and by popular philosophers. To be more specific, Kant's metaphysics lectures followed A. G. Baumgarten and F. C. Baumeister, his lectures on natural religion J. A. Eberhard, on practical philosophy A. G. Baumgarten again, on logic G. F. Meier, on natural science E. C. P. Erxleben, and on natural right Gottfried Achenwall. As we already know, in his lectures on philosophical encyclopedia he followed J. G. H. Feder. Some of these authors were much younger than Kant and had a predilection for popular philosophy.

Be that as it may, Kant did not treat his lectures as insignificant and prepared some of them for print, the most celebrated being his lectures on logic edited and published by G. B. Jäsche in 1800 (Log, AA 9). Apparently, Kant believed that the practice of lecturing, referring to compendia and manuals, even if they were not of best quality, helped in developing a synoptic view in philosophy. In particular, it can help to chart a program for, what we are going to call here, a "diachronic encyclopedic approach" in philosophy (to be discussed in $\S 3$ ) which accompanied his project for transcendental philosophy. In contrast to it, the program followed in his lectures on philosophical encyclopedia can be called a program for "synchronic encyclopedia of philosophy."

3. Kant's way to the diachronic encyclopedizing philosophy

Significantly, while Kant and his friends were deeply impressed by the work of the French encyclopedists, they considered it a failure. Towards the end of December 1759, Johann Georg 
Hamann wrote to Kant: "D'Alembert and Diderot wanted to add to the honor of their nation an encyclopedia; they failed. [...] The flop of their project could be more instructive than its [eventual] success" (Br, AA 10: 27-28). Kant strongly agreed with this judgment. In the margins of his copy of G. F. Meier's Auszug der Vernunftslehre (1752) he programmatically noted: "to determine in advance [zum voraus] the absolute horizon of the whole human race (as to past and to future time)"3 (HN, AA 16: 189; Log, AA 9: 43).

In short, as Kant was inspired by the French project for an encyclopedia, he decided to develop it in his own field of study - philosophy - in an alternative way. While the French encyclopedic movement of the mid-eighteenth century aimed to achieve a comprehensive but extensive account of human knowledge, Kant's idea was to make use of practically all eminent ideas in western philosophy, elaborated in its long history, with the intention of synthesizing them all. ${ }^{4}$ Moreover, he was convinced that they could be put together so as to logically fit one another in the strictest way. Nobody understood this project of Kant's better than Hegel who developed a full-blown logically organized encyclopedic project in philosophy. Hegel was adamant that "the encyclopedia of philosophy must not be confounded with ordinary encyclopedias. An ordinary encyclopedia does not pretend to be more than an aggregation of sciences, regulated by no principle, and merely as experience offers them" (1830, § 16). In contrast, the philosophical encyclopedia is logically structured and guided.

In order to better understand this idea of Kant's, we can remind the reader that according to him, philosophy is always done historically, in the form of this or that philosophical school. In truth, however, in respect of its matter, it is one and the same (PhilEnz, AA 29: 32). This two-faceted nature is characteristic of philosophy but not of mathematics; the latter discipline explores a priori knowledge which constructs a priori concepts that students can learn. In contrast, there is nothing to learn in philosophy - it produces nothing new; it simply elucidates, clears up the principles of reason..$^{5}$ Philosophy's masters only try to explicate these principles. In this sense, we cannot learn philosophy; we can only learn to philosophize, that is, to find some particular, historical form to present the principles of human reason ( $\mathrm{KrV}$ A837-8/B 865$6)$.

\footnotetext{
${ }^{3}$ Kant, Immanuel (1992): Lectures on logic. Michael Young (Ed. and Trans.). Cambridge: Cambridge University Press.

${ }^{4}$ This interpretation can be underpinned with a quotation from Georg Christoph Lichtenberg's letter to his brother Ludwig Christian of 18.02.1799: "Kant doesn't pose himself as a discoverer of everything, he only connects what great men had once said and thought of" (1967: 1011).

${ }_{5}^{5}$ Many years later, Wittgenstein will rediscover this position.
} 
To be more explicit, the principles of human reason are a kind of archetype (Urbild). What can be achieved in philosophy at all is only the outline of a copy of this archetype. This is also the objective of Kant's transcendental philosophy: to facilitate the overall view of the principles of reason (and ipso facto of the discipline of philosophy), producing a perfect copy of it. To this end, he purposely referred to variegated philosophical conceptions, crystallized in the course of history, which outlined the principles of reason in specific forms.

This understanding theoretically justifies Kant's diachronic encyclopedic effort to summarize all discoveries, ever made in philosophy, in an attempt to produce an ultimate philosophical manual, or a textbook for philosophy students to learn from. As a matter of fact, Kant deemed for years to write $\mathrm{KrV}$ as a "manual" [Handbuch] (GMS, AA 4: 582; Br, AA 10: 241). This character of the book is actually the source of the notorious obscurity of Kant's transcendental philosophy, its unavoidable dryness and scholastic precision. It is similar to the obscurity of any comprehensive grammar, or logic textbook: "the principle points of the investigation [in them] are easily lost sight of", (Prol, AA 29: 16).

4. Kant's diachronic philosophical encyclopedia

Let us provide some illustrative examples of Kant's diachronic philosophical encyclopedia.

Kant widely used the achievements of the atomistic philosophy of Locke and Hume and the method of analysis followed by them. He, however, departed from Locke and Hume when he decided to include mathematics in his conceptual scheme- the British Empiricists (but George Berkeley) and also the French materialists showed less interest in that discipline. In this way, Kant paid respect to the German rationalists Leibniz and Wolff, thus putting them in an encyclopedic equilibrium to the empiricists and the materialists. The inclusion of mathematics into his critical examination convinced Kant that there were a priori forms of human reason. Following his encyclopedic approach in philosophy, however, he considered them to be deeply embedded in experience.

Kant also reintroduced the problem of insolubilia in philosophy which is completely forgotten in modern Europe. He realized that when we start to explore "things in themselves" - objects that we do not know through experience - antinomies appear with necessity. The problem is that reason has the natural inclination to unify (to systematize) the

\footnotetext{
${ }^{6}$ Kant, Immanuel (1996): Prolegomena to any future metaphysics. Beryl Logan (Ed.) and Paul Carus (Trans.). London: Routledge.
} 
appearances. In this way it postulates the ideas of soul, world, and God. These postulates, however, have only a regulative function.

The last example demonstrates that adherence to the encyclopedic approach in philosophy can bring to light new concepts and perspectives on them; in this case, the concept of "regulative idea" that would otherwise remain unnoticed and unexplored. In general, the encyclopedic tilt in Kant's project helped him to reach unprecedented power to clarify the principal concepts and categories of philosophy, thereby advancing many ideas that would be rediscovered by the upcoming phenomenology and analytic philosophy.

Kant further brought mathematics and philosophy together-both pursue conceptual knowledge. Mathematical knowledge constructs concepts on the basis of intuition, whereas philosophical knowledge is the knowledge of given concepts-it analyzes them. A corollary of this position is that in mathematics we start with the evident, simplest, and clearest data- the data of intuition, for example, from the concept of number, or line, in order to reach most complex theories and calculi. In contrast, in philosophy we begin with what is vague (dunkel) and complicated (for example, with the concepts of freedom, or soul), the task being to ultimately elucidate it, to make it clear and distinct. In other words, while the mathematical method is progressive (constructing complex theories from elements known via intuition), the philosophical method is regressive (KrV, A 713ff./B 741ff.). ${ }^{7}$

Concepts are analyzed not only by philosophy, but also by logic. That is why philosophy and logic are deductive disciplines. ${ }^{8}$ To put this point of Kant's in other words, given (including a priori given) concepts are defined through analysis. To be more precise, "one can make given concepts distinct only insofar as one successively makes their marks clear"9 (Log, AA 9: § 104). Kant called this practice exposition of concepts which, however, could also be imprecise. In such cases we have description of concepts.

Made (constructed) concepts are defined through synthesis - through a priori synthesis, in mathematics, or through a posteriori synthesis, in science. Mathematics does this "arbitrarily" (or creatively) and science, empirically. Mathematics constructs concepts and science exposes appearances (as just seen, philosophy exposes concepts). This explains why only concepts of mathematics can be defined while those of science cannot have definitions as the scientific concepts are derived from experience "and as such can never be complete" (Log, AA 9: § 103).

\footnotetext{
${ }^{7}$ In (1907) Bertrand Russell, who was anything but a Kantian philosopher, virtually repeated this position of Kant's.

${ }^{8}$ Philosophy is a deductive discipline since it starts from human experience which is already there, is given, and which tries to deduce from it the concepts, categories, schemata and principles that make it possible.

${ }^{9}$ It deserves notice that this clear definition of analysis was out of reach for generations of analytic philosophers.
} 
Kant's encyclopedic stance also found expression in his project to logically connect theoretical and moral philosophy. Furthermore, in the Critique of the Power of Judgment he built a bridge between the faculties of understanding (epistemology) and reason (ethics) with the help of a critique of the faculty of judgment. Most importantly, however, Kant married philosophy to logic (another discipline, besides mathematics, that was consigned to oblivion in modern Europe). In $\mathrm{KrV}$ logic served as a basis (a template) for the transcendental deduction of the categories, schemata and principles of human understanding (Milkov 2013, 662). Adopting this approach, Kant radically separated form and content, introducing in this way the "formal logic" in philosophy. (The latter was severely criticized not only by Hegel but also by Frege.) The ultimate task of Kant's transcendental deduction was to explicate (herauszuschälen) the constitutive elements of human reason and its boundaries. These are the a priori constitutional conditions which are realized by the transcendental unity of consciousness, making in this way human experience and also sciences possible.

The logical character of Kant's transcendental philosophy is also prominent in his insistence that it is a formal science that seeks academic precision. Its propositions are to be exposed systematically down to its minutest points. In this respect, it is on a par with logic, sciences and mathematics. ${ }^{10}$

\section{Reception and furtherance of Kant's encyclopedic project}

Kant's transcendental philosophy triggered a landslide in western philosophy. He fundamentally brought it to a new level. Whereas a few philosophers followed his "Copernican revolution", putting at the center of their explorations the cognizing person, many of them tried to digest, criticize and eventually to overcome his transcendental philosophy, retaining, however, its encyclopedic character. Importantly enough, the most fruitful influences of Kant's philosophy were realized this way, not in attempts to directly follow or develop his philosophy. ${ }^{11}$ This exercise was practiced by philosophers with quite different intuitions and temperaments such as Hegel and Schopenhauer, Lotze and Husserl, and Bradley and Sidgwick. For this reason alone, the diachronic encyclopedic approach in philosophy, introduced by Kant, paid off. On the one hand, it renewed philosophy and, on the other, it helped to better understand its past masters.

\footnotetext{
${ }^{10}$ Gottlob Frege typically insisted that there were no minute details in logic. In this realm any detail is important.

${ }^{11}$ This found expression in the abrupt disappearance of the Neo-Kantians as main players on the philosophical scene after the First World War.
} 
To be more explicit, from the very beginning, the revision of Kant's encyclopedic approach concentrated on the role of logic in it. First, Karl Leonhard Reinhold pointed out that the logic of Kant's philosophical system was inadequate since it had no first principle. By way of filling this gap, Johann Gottlieb Fichte claimed to have discovered a new ground, out of which one could expand the whole critical philosophy. It is the Ego (das Ich) that recognizes itself as its self-creation.

Hegel adopted many of the critical arguments of his contemporaries against Kant, including the criticism of the flaws in his logical system. His answer to Kant, however, was principally different. Hegel's Logic was a hyper-grand philosophical theory whose objective was to explain the development of the world spirit as an "absolute idea." The latter explicates itself in the form of categories of human understanding. This is a process driven by contradictions that at the end reaches the absolute truth. The explication of categories is explicitly encyclopedic. It starts with the most abstract ones - being, quality, quantity, measure, etc. - and ends with categories defined clearly: the categories of mechanism, chimism, teleology, organism, and knowledge.

Only Hermann Lotze eliminated the strict logical connections between different philosophical concepts, categories and principles but retained Kant's encyclopedic approach. Moreover, Lotze defended what Bertrand Russell would later call a “piecemeal," step-by-step way of doing philosophy (1918: 85). Its main points are not logically dependent. Philosophy propositions have value of their own. They don't lose it when they are used autonomously beyond the system. Correspondingly, Lotze instructed his readers to regard his philosophy as "an open market, where the reader may simply pass by the goods he does not want" $(1874,4)$.

Jakob Friedrich Fries made efforts to revise another point of Kant's project. He connected the deduction of categories and principles of knowledge with the ever-changing new achievements of science. Kant correctly maintained that human knowledge was based on a priori principles. These principles, however, change with the development of the knowledge — of science and mathematics. In this sense they are relative. In this way Fries introduced the practice of exploring the "relative a priori" in philosophy (it was called as such much later). This amendment of Kant's transcendental philosophy was adopted and further developed by Leonard Nelson, Karl Popper and Hans Reichenbach (Milkov 2012).

Especially critical of Kant was Franz Brentano. He rejected Kant's formalism which produced "philosophical monstrosities." Kant's discrimination between form and qualia, for example, is not based on scientific discussion but is introduced through voided a priori metaphysical deliberations. In contrast, Brentano "empirically" (introspectively) explored the 
phenomena of consciousness that are immediately given to us. This approach was further developed of Edmund Husserl. On one side, Husserl's phenomenology followed Kant's method of deducing philosophical concepts and categories. On the other side, he tried to directly (immediately) discover them in a laborious process of philosophical meditation.

Notably, while these most prominent—and most fruitful—revisions of Kant's transcendental philosophy were critical of its logic, they retained the main elements of his encyclopedic program. In this way they demonstrated its theoretical excellence.

\section{Bibliography}

Baumgarten, Alexander (1769): Sciagraphia Encyclopaediae Philosophicae. Christian Förster (Ed.). Halle: Hemmerde.

Darnton, Robert (1984): "Philosophen stutzen den Baum der Erkenntnis: Die erkenntnistheoretische Strategie der Encyclopédie”. In: Christoph Conrad/Martina Kessel (Eds.). Kultur \& Geschichte: Neue Einblicke in eine alte Beziehung, Stuttgart: Reclam, 209241.

Feder, Johann Georg Heinrich (1767): Grundriß der Philosophischen Wissenschaften nebst der nötigen Geschichte zum Gebrauch seiner Zuhörer. Coburg: Johann Carl Findeisen.

Hegel, G. W. F. (1830): Logic, being Part One of the Encyclopedia of the Philosophical Sciences. William Wallace (Trans.). Oxford: Clarendon Press, 1975.

Lehmann, Gerhard (1961a): “Einleitung zur Enzyklopädievorlesung”. In: PhilEnz, AA 29: 6974.

Lehmann, Gerhard (1961b): “Allgemeine Einleitung”. In: PhilEnz, AA 29: 7-27.

Lichtenberg, Georg Christoph (1967): Briefe, 4. Band von Schriften und Briefe, in 4 Bände. Wolfgang Promies (Ed.). München: Hanser.

Lotze, Hermann (1874): Logic, $2^{\text {nd }}$ ed. Bernard Bosanquet, et al. (Trans.). Oxford: Clarendon Press, 1887.

Meier, Georg Friedrich (1752): Auszug der Vernunftlehre. Halle: Johann Gebauer.

Milkov, Nikolay (2012): “Karl Popper's Debt to Leonard Nelson”. In: Grazer philosophische Studien 86, 137-56.

Milkov, Nikolay (2013): “Kant's Transcendental Turn as a Second Step in the Logicalization of Philosophy”. In: Stefano Bacin, et al. (Eds.): Kant and Philosophy in a Cosmopolitan Sense: Proceedings of the XI. International Kant Congress. vol. 1, Berlin: de Gruyter, 655-67.

Russell, Bertrand (1907): “The Regressive Method of Discovering the Premises of 
Mathematics". In: idem, Essays on Analysis. D. Lackey (Ed.). New York: Braziller, 1973, 273-83.

Russell, Bertrand (1918): Mysticism and Logic. London: Allen \& Unwin, 1963. 